\title{
История и современность
}

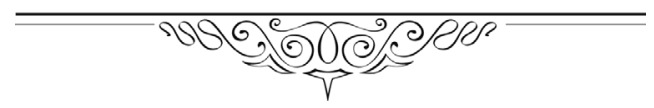

УДК 94:025.173

DOI: $10.22378 /$ kio.2020.2.8-18

\section{Гаспринскийнинъ газета чыкъармасына рухсетнаме ичюн дипломатик куреши}

\author{
Исмаил Керим \\ (Татарстан, Джумхуриети Илимлер Академиясы, Ш. Марджани \\ адына тарих Институты; Кьырым муэндислик ве педагогика \\ университети)
}

Анълатма. Ишбу чалышмада И. Гаспринскийнинъ 1881-1882 сенелеринде С.-Петербург цензура тешкилятындан Багъчасарайдаки эвинде шахсий матбаа ачмакъ ичюн рухсетнаме алмакъ ичюн япкъан ве эдинген арекетлери косьтериле. Къыскъа шекильде «Тонъгъуч» (1881), «Шафакъ» (1881) ве «Терджиман» (1882) варакъаларынынъ нешри хусусында сёз юрютиле.

Анахтар сёзлер. И. Гаспринскийнинъ ильк неширлери, 1880-нджи сенелеринде Багъчасарайдаки озель /шахсий/ матбаа, XIX асырнынъ сонъларында Къырымда газета чыкъармакъ меселелери, Русиеде мусульман джеридеджилиги.

Мевзунынъ актуаллиги. И. Гаспринскийнинъ ильк макъалеси къачынджы йылы басылды ве шу макъале не акъкъында эди? Бу меселе иле шимдигеджек кимсе махсус огърашмагъаны корюнмекте. Ама якъында профессор Илья Зайцевнинъ «Крымское историческое обозрение» дергисинде басылгъан бир макъалесинде бунъа аит белли дереджеде айдынлыкъ берильмекте [1, с. 175-179]. И. Зайцевнинъ хаберине коре, Москвадаки Русие эдебият ве санат девлет архивинде И. Гаспринскийнинъ 1876 ве 1882 сенелерине аит эки мектюби сакъланмакъта. Биринджиси «Новое время» газетасынынъ янъы сахиби А. С. Суворинге адалгъан. Бу ерде И. Гаспринский кендисининъ 1875 сенеси Тюркиеден «Шаркъ мектюплери» серлевхасынен «Новое время» газетасына кондерип бастыргъан макъалелери хусусында сёз юрьсети- 
лип, языларнынъ къаршылыгъына «Новое время» газетасыны бедава алгъаныны хатырлата. Яни бу хаберге эсасланып, бугунь биз И. Гаспринскийнинъ ильк корреспонденциялары 1875 сенеси басылгъанлары акъкъында айтмагъа акъкъымыз бар.

12 декабрь 1882 сенеси Русие матбаа ишлери боюнджа баш идаренинъ мудири П. П. Вяземскийге язылгъан экинджи мектюпке келиндже (кельгенде), мында Гаспринский «Терджиман» газетасынынъ чыкъарылмасына рухсет истеп, онынъ рус администрациясы ве рус медениети ичюн файдасыны анълатмакъта [1, с. 177-178].

Бильгенимиз киби, «Терджиман»нынъ нешрине рухсетнаме алмакъ ичюн Гаспринский аслында чокъ вакъыт ве чокъ кучь сарф эткендир.

Бугуньде Къырым девлет архивинде къорунмакъта олгъан чешит весикъалар арасында Гаспринскийнинъ озель (шахсий) типография ачмасы ве газета нешри ичюн рухсет алынмасы меселелеринен багълы бир сыра меракълы худжджетлер булунмакъта.

1882 сенеси январь 9-да Таврия губернаторы адына Гаспринский бойле бир хабер тезкереси (докладная записка) кондере: Татарларнынъ якъын арадаки эгитими ве маарифине хызмет этмек ниетинен ве чешит ильмийамелий бильгилерни оларгъа озь тилинде огренмелерине фурсат эдинерек, бир чокъ макъале ве очерклерни татарджагъа чевирдим. Эм бу меселеде бир теджрибели оджа сыфатында мезкюр бильги берильмеси эснасында адий шекиллерден башлап муреккеплерине ёнелиш туттум. Чюнки авам халкъкъа саде бильги берильмесининъ ёлу будыр. Иште бойле бильгилерни айры сахифелер (газет сахифелери) шеклинде нешир этмеге ниет эдиндим. Ишбу неширлернинъ мундериджесини илимнинъ чешит сааларына аит адий бильгилер озель ве терджиме этильген парчалар тешкиль этеджектир. Булар арасында укюмет тарафындан илян этильген къанун-къаиделер, харбий низамнамелер, икяелер, чешит лятифелер, айтымлар, санат ве эснафлар иле багълы малюмат ве хаберлер, мектеп ишлери, рус ве четэль хаятында олып кечкен эмиетли левхалар булунмакъта. Бутюн булар адий халкънынъ анъламасы ичюн келиштирильгендир. Ве аслында, юкъарыда анъылгъан малюматнынъ джумлеси - татарларны рус халкъынынъ медениети ве маарифи иле таныштырып, оларнынъ рус илиминден сакъынмасындан вазгечтирмектир [2]. Тезкеренинъ девамында Гаспринский эки нешир макинеси пейда эткени ве шулардан бириси литограф макинеси ве эр эксине кирил ве татар (араб) шрифтлерини алгъаныны хабер эте.

Бу ерде анълашыла ки, не ичюн Гаспринский 1881 сенесинде кендисининъ «Тонъгъуч» («Первенец») ве «Шафакъ» («Заря») газетимси (газетасы) сахифелерини Къырымда дегиль де, Тифлисте мухаррир Унси-заденинъ типографиясында, нешир эттирген эди [3; 4]. Яни 1881 сенеси Гаспринскийнинъ элинде матбаа макинелери даа ёкъ экен... Эм де бойле макине пейда эткени 
хусусында энди илян бергени ве бу илянны матбаа юзюне чыкъармакъ ичюн С.-Петербург ич цензурасы комитети тарафындан махусус рухсетнаме алгъаны ве оны Илимлер Академиясы типографиясында бастыргъаныны анълата.

Гаспринский кенди матбаа макинелеринде бастыргъан биринджи варакъа 1882 сенесине аит олып, басмаханенинъ адыны ве нешир ерини бойле шекильде къайд этмекте: «Багъчасарай: Нешрият-и-Исмаилие» ${ }^{1}$ [5].

Мезкюр хабер тезкересинде Гаспринский дей ки, бу олай, яни типография макинелери сатын алынмасы ве тувгъан тильде чешит эсерлер нешир олунаджагъы, къырымтатарлар тарафындан алгъышлар ве истекле къабул этилип бунъа даир онъа мектюплер кондердилер.

Эсас къысым. Гаспринскийнинъ фикриндже, ишбу варакъалар (листы) айры неширлер шеклинде олып, С.-Петербург комитетинде цензурадан кечеджектирлер. Булар айры-айры мевзуларгъа багъышланып, вакъыт мусааде этсе, йыл ичинде 50 ве бельки бундан даа зияде номерлер чыкъармагъа макъсат эдиниле. Ишбу варакъалар «Ай», «Кунеш», «Кунь», «Мектеп», «Тербие», «Дюнья», «Хава», «Денъиз», «Хайванат», «Осюмликлер», «Минераллар», «Эснафлар», «Макинелер» киби мевзуларда дердж этиледжек. Къарарлаштырылгъанына коре, варакъаларнынъ данесине 8 капик, джумлеси (коллекциясы) исе, 3 кумюш фиятында оладжакътыр. Варакъалар эм перакенде (бирер-бирер), эм де топтан сатылып, истеклилернинъ исе, буларгъа абуне олып эльде этмелерине чарелери булунаджакъ.

Ишбу неширлер периодика сайыламаз, чюнки Русиедеки матбуат къаиделери боюнджа, периодика олмасы ичюн башталары бир серлевха алтында чыкъарылмалылар...

Гаспринский Таврия губернаторына язгъан хабер тезкересинде юкъарыдакилерни ачыкълаяракъ риджа эте ки, буюк бильги сахиби губернатор хазретлерининъ булардан хабери олсун, ве Матбаа ишлери баш идаресине мураджаатында меселени ачыкъладыгъы заман, татарджа нешир меселесини кенди юксек химаеси алтына алсын дее ильтимаста (риджада) булуна.

Эм де фурсаттан файдаланаракъ, Министерствонынъ (Назирликнинъ) бутюн тевсиелерини баш усьтюнде къабул этип, кучюне коре, ялынъыз Ватанымыз файдасына, татарларнынъ маарифи огърунда чалышаджагъыны анълата. Ишнинъ муваффакъиети корюндикче, татарджа (русчагъа чевирмелери

${ }^{1}$ Бир газет табагъында къырымтатарджа ве русча материаллар топламы. Бу ердеки кириш сёзюнде И. Гаспринский русча оларакъ бойле язмакъта: «Значительный успех наших небольших, пробных изданий на татарском языке и внимание, оказанное им мусульманами, обязывают нас отнестись с полной серьезностью к столь полезному делу, вследствие чего, имея основной целью знакомить русских мусульман с Россией, как с их отечеством, так по возможности и с европейской культурой, мы полагаем вдвойне полезным печатать наши труды параллельно по-татарски и по-русски, если силы наши то позволят. Это наш первый опыт, почему просим читателя быть снисходительным к его недостаткам». 
иле) куньделик нешир ачылмасына истеклер ве риджанамелер бильдириледжеги арз этиле.

«Къырымтатарларынынъ чокъсунда олгъан окъур-язарлыгъындан файдаланып, келеджекте дюнья юзю кореджек неширлер вастасынен оларнынъ анълайыш ве корюшлерине тесир быракъып, рус миллетине якъынлашма меселесинде базы хурафат ве кёр инанчларыны эксильтмек мумкюн оладжакътыр. Татарларнынъ эгитими ве маарифи саесинде рус ве татарларнынъ акъикъий бирлиги огърунда хызметни арз этем» [2, л. 2] - дей Гаспринский. Яни къырымтатарджа куньделик матбуатындан «отю патлагъан» (къоркъкан) (оставить оба слова; къоркъкъан будет как уточнение) чар мемурлары ве цензорларынынъ элинден рухсетнаме алмакъ ичюн Гаспринский чешит усуллар ве ёллар араштыра ве энъ эсас ёл «чар девлетине хызмет этмек» ёлуны озьджесине оларгъа анълатмагъа чалыша.

Бу фикир онынъ язгъан бир чокъ аризаларында, арзнаме ве риджанамелеринде текрарланмакъта. 1882 сенеси январь 9-да язылгъан биринджи мектюбинден там бир ай кечкенинден сонъра, яни 1882 сенеси февраль 9 куню Гаспринский Таврия губерниясынынъ начальнигине бойле риджанаме (прошение) кондере: Нешир эткен биринджи варакъаларымнынъ халкъ арасындаки муваффакъиетини ве олар тарафындан ёлланылгъан алгъышлайыджы мектюплерини козь огюне аларакъ, мен бойле нетиджелерге кельдим. Бу шекильдеки популяр неширлер саесинде мусульманларнынъ хаятындаки дургъунлыкъ, фаалиетсизлик ве анълы оларакъ Ватанымызнынъ медениети ве хаятына къошулмакъ меселесинде баладжасына тюшюнджелерини ве шупхэлерини кидермек имкяниетлери булунмакъта. Мен исе, кенди тербием ве инанчларым джихэтинден бир рус киби олдугъымдан, бу меселеде самимий шикильде файдалы олмакъ истерим. Шунынъ ичюн Багъчасарай шехринде татарджа-русча афталыкъ популяр бир варакъа нешрине башламакъны арз этем. Бу варакъаларда ялынъыз русча менбаларда корюнген ресмий хаберлер ве чешит макъалелернинъ терджимелери булундыгъы саесинде сиз, хашиметли хазретлерине риджада булунам ки, буны юкъары реискарделерге сунманъыз ве меселени чезменъизни риджа этем [2, л. 5].

Дикъкъат этмели, 1882 сенеси февральде газета чыкъармакъ дегиль де, ич олмадым бир газета варакъасы чыкъармакънынъ чареси араштырылмакъта.

Кене шу куню, яни 1882 сенеси февраль 9 куню, кене Таврия губерниясынынъ начальнигине Гаспринский даа бир риджанаме кондере. Тамам бу риджанамеде юкъарыда анъылгъан эки матбаа макиненинъ тафсиляты ачыкълана. Яни Гаспринский тарафындан сатын алынгъан эки матбаа макинеси «эль макинелери» (ручные станки) экен [2, л. 6]. Эм шулардан бириси литография макинеси олгъаныны энди къайд эткен эдик. Ишбу риджанаменинъ янына Гаспринский типография тутулмасына тиджарет шахадетнамеси ве берилед- 
жек рухсетнамеге япыштырмакъ керек олгъан марканы да къошып озь эвинде шахсий типография ачылмасына мусааде сорамакъта.

Меселе бу дереджеге еткен сонъ, вицегубернатор, табий, гизли шекильде Таврия губерниясы жандарм идаресининъ мудирине мураджаатта булуна. 1882 сенеси апрель 26-да язылгъан бу весикъада ашагъыдакилер корюнмекте: «Алий хазретлерине итааткярлыкъле мураджаат этерек, матбаахане ачаджакъ олгъан Багъчасарай шехэр головасы Гаспринскийнинъ сиясий гувенирлиги ве ахлякъий сыфаты акъкъында хабер верменъизни истер эдим» [2, л. 7]. Иште, бу мураджааткъа Шлейфер (?) сойадлы Багъчасарай полициймейстеринден Таврия губернаторына гизли шекильде бойле рапорт кондериле: «1882 сенеси апрель 26-да эда этильмеси ичюн кондерген эмиринъизге джевабен, хазрет-и-алийлеринъизге хабер этем ки, Багъчасарай шехэр головасынынъ (Гаспринскийнинъ) хаят ве харекет тарзы пек гузель олып, ич бир айып яхут чиркин халларда булунмасы белли дегильдир» [2, л. 7].

Гаспринскийге гизли шекильде полициймейстер тарафындан бойле мусбет характеристика берильген сонъ, 1882 сенеси август айынынъ 18-де вицегубернатор тарафындан разылыкъ шахадетнамеси бериле. Къырым девлет архивинде шахадетнаменинъ кендиси де булундыгъындан, ве бу весикъанынъ миллетимиз ве умумен Русие мусульманлары ичюн гъает буюк эмиети олдугъындан, онынъ оригиналыны сакълаяракъ (яни русча вариантыны) беремиз:

«Свидетельство.

Дано сие Свидетельство Дворянину Исмаил-бею Гаспринскому в том, что ему разрешается иметь в г. Бахчисарае типографию с тем, чтобы во время действия типографии Гаспринским были выполняемы все условия, как предписанные Высочайше утвержденным в апреле 1865 года мнением государственного Совета о типографиях, литографиях и проч., так и имеющие последовать правительственные по этому предмету распоряжения и указания. Причитающийся гербовый сбор уплачен, 18 августа 1882 года, г. Симферополь.

За Таврического Губернатора (Вице губернатор)» [2, л. 11].

Ишбу рухсетнаме Гаспринскийнинъ газетаджылыкъ ёлунда биринджи гъает эмиетли ве джиддий гъалебеси эди. Чюнки эвде шахсий типография тутмакъ меселеси ялынъыз къырымтатары ичюн дегиль, Русиенинъ эр бир шахсы ве тебаасы (гражданы) ичюн чокъ зор эди. Ве бильгенимиз киби, сонъундан бу адым («Терджиман» газетасы чыкъмагъа башлагъан сонъ) бутюн Русие мусульманларынынъ хаятына чокъ буюк тесирлер быракъкъандыр.

Эм де тамам бу рухсетнамеден сонъ Гаспринский 1882 сенеси «Терджиман» адлы сахифесини (варакъасыны) чыкъара бильди [5]. Табий, шу варакъаны «Терджиман» газетасындан айырмакъ лязимдир.

1881 сенесинден башлап биринджи чыкъаргъан варакъаларнынъ яйгъынлыгъы, популярлыгъы ве сатылыш тезлигинден, газета чыкъармакъ ишининъ мумкюнаты да анълашылды. Чокъкъа сюрмеден Гаспринский Русиенинъ ич 
ишлер назирине (министрине) афтада бир дефа русча газета (татарджагъа терджимеси иле) чыкъармакъ шартынен рухсет берильмесине мураджаатта булуна. Газетанынъ адыны «Переводчик» («Терджиман») къойып мухаррирлигини кенди япаджагъы ве кунь эввель цензуранынъ рухсетини аладжагъы анълашыла. Ама Гаспринскийнинъ шахсиетинен кене айрыджа меракъланмагъа башлайлар. Бу дефасында Генерал-Адъютант Гурко 1882 сенеси октябрь 14-те гизли шекильде Таврия губернаторына мураджаат этип, бу меселеде онынъ фикри ве нетиджелемесини сорамакъта [2, л. 12].

Даа да тафсилятлыджа ачыкъланаджакъ олунса, мисаль оларакъ ашагъыдакилерни кетирмек мумкюн. Гаспринский акъкъында нелер билинеджек олуна: 1. Къайда ве къайсы окъув юртунда тасиль алды? Насыл фенлерни огренди? Ильмий дереджеси бармы?

Багъчасарай полициймейстери бу суаллерни Гаспринскийге еткизген сонъ, о, язылы шекильде джевабен бойле малюмат бере:

Мен Москвадаки 2-нджи харбий гимназияда окъудым. О ерде кечкен дерслеримден: русча ве франсызджа тиллер, рессамджылыкъ, ситуация (педагогика бильгиси), тарих, джогьрафия, джебир (алгебра) ве хэндесе (геометрия). Булар 1277 номералы шахадетнамемде къайд этильгендир.

Сонъра Акъмесджитте 531 номералы гимназияда окъудым. Имтиханлар берип Шехэр оджасы сыфатлы зенаатны къазандым.

Алты сене девамында чешит мектеплерде къырымтатар талебелерине рус тилинден дерс бердим ве эйи чалыштыгъым саесинде Одесса Окъув Даиресининъ мудиринден тешеккюрнаме къазандым. Шу весикъа (тешеккюрнаме) манъа 1872 сенеси апрель 10-да берильди. Номерасы 283.

Алий ильмий дереджем ёкъ. 1879 сенесинден башлап татарджа оларакъ чешит варакъа ве брошюралар нешир этмектем. Эр бири 1000 нусхада сатылмакъта [2, лл. $17,18,21] \ldots$

Бу ерде биз ичюн пек меракълы малюмат бар. Гаспринский кенди неширджилик фаалиетини 1881 дегиль де, 1879 сенесинден косьтере. Ве ялынъыз варакъалар дегиль де, «татарджа оларакъ брошюралар» дердж эткени хаберини язылы шекильде бермекте. Демек ки, биз бу замагъаджа бильген ве тапып олгъан материалларымыз толу дегиль. Бугуньгедже Гаспринскийнинъ биринджи нешир эткен махсулуны «Тонъгъуч» (1881) деп билемиз. Эм де «тонъгъуч» сёзюнинъ манасыны да «энъ эввельки», «биринджи» киби билемиз... Эр алда, Гаспринскийнинъ язылы шекильде берген хаберине, яни нешир ишлерини 1879 сенеси башлагъанына, джиддий эмиет берип бу хусустаки араштырмаларны даа индже шекильде девам этмели.

Бу сонъки весикъада, Гаспринскийнинъ къайд эткенине коре, газета нешрине рухсет алынса, онда иштирак этмесине оджалар семинарияларынынъ инспекторлары ве алий окъув юртларында шаркъ тиллерининъ базы муаллимлери де разылыкъ бергенлер. 
Эм архивнинъ тамам бу папкасында 1882 сенеси август 5-те С.-Петербург цензурасы тарафындан рухсет этилип неширден чыкъкъан «Терджиман» варакъасынынъ кендиси (оригиналы) булунмакъта. Колеми чокъ буюк олмайып 4 сахифеден ибареттир. Ич къысмында ялынъыз къырымтатарджа, тыш къысмында исе, ялынъыз русча метинлер ерлештирильген. Базы макъалелерининъ серлевхалары булардыр: «Енъи къанун-къаиделер», «Къадынларны окъутмалымы?», «Русие», «Русиедеки мусульман матбаасы». Иште, бу варакъада Гаспринский ильк дефа оларакъ кенди шахсий матбаасынынъ адыны къайд эткендир: «Багъчасарай: Нешрият-и-Исмаилие».

Гаспринскийнинъ эсас макъсады, эбет, варакъа дегиль де, газета чыкъармакъ эди. Эм арекетлеринден корюне ки, о, озюндже яваш-яваш кенди макъсадына «джылышмакъта» эди. Цензурадаки мемурларнынъ назарыны ве дикъкъатыны ичтимаий ве сиясий меселелерден четлештирмек ве узакълаштырмакъ, татарлар акъкъындаки фикирлерини булардан узакъ тутмакъ ниетинен, озюнинъ чокъусы мураджаатларында энъ чокъ ве энъ сыкъ оларакъ мутат, яни урф-адетлерге, хаятий олайларгъа меракъ чектире. Таврия губернаторына олгъан мураджаатларындан биринде дей ки, «кендим нешир эткен варакъаларымда миллетке файдалы бильгилер бергенимден ве хусусан бойнузлы хайванлардаки таун (чума) хасталыгъыны кидерме, яхут тыртырларгъа (гусеницы) къаршы куреш меселесиндеки тевсиелер гъает эмиетли олдулар. Аслында халкъымыз буларны «Аллахын джезасы» олдугъы киби къабул этерек, къаршылыкъ япмагъа хич де харекет этмездилер» [2, л. 22].

$\mathrm{Be}$, акъикъатен, ниает, «буз еринден кочьти»... Русие империясынынъ ич ишлери назири Д. А. Толстой (1823-1889) И. Гаспринскийге газета чыкъармасы ичюн рухсетни берди. Табий, газетнинъ эр бир номери чыкъмаздан эввель С.-Петербург цензура тешкилятындан кечмели эди. Ве Гаспринскийнинъ кендисинден хусусий бир сенет (расписка) алынмалы эди ки, кенди нешир хакъкъыны, Матбуат меселелери баш идаресининъ разылыгъы олмадан, дигерине верильмеси ясакътыр [2, л. 25].

Бугуньдеки анълайышларымызгъа коре, къырымтатарджа чыкъкъан газета русчагъа терджимеси иле дегиль де, аслында рухсет русча («Переводчик») чыкъкъан газетаны татарджагъа («Терджиман» адынен) терджимеси иле олгъанына бериле! Буны Русиенинъ Матбуат меселелери боюнджа баш идаресининъ мудири Феоктистов Таврия губернаторына хабер эте [2, л. 25].

Эм Феоктистов Таврия губернаторына бойле риджада булуна. Рухсетнаме берильгени хусусында Гаспринскийге хабер этип, бу меселе иле багълы къоюлгъан шартларгъа имза чектирмек. Имза чекильгенинден сонъра, рухсетнаме берильгени акъкъында илянны къолуна туттурып, ондан 60 капиклик къыйметинде олгъан учь дамгъалы марка алып, имзалангъан кягъытле бераберликте Матбуат ишлери боюнджа баш идареге кондермели. 
Озь невбетинде Таврия вице губернаторы 1883 сенеси мартнынь 2-нджи куню Багъчасарай полициймейстерине мураджаатта булунаракъ, Матбаа ишлерининъ баш идареси 1883 сенеси 16 февраль куню 688 номералы буйругъынынъ эдасыны ерине кетирмек ичюн Гаспринскийге адалгъан 685 ве 686 номералы шахадетнамелерини онынъ элине берип, алдыгъы хусусында имзасыны чектирмекни буюра.

Ве деребей (дворянин) Гаспринский ичюн газета ачмакъ рухсетнамеси меселесинде весикъалар джедвелининъ ахырысы Багъчасарай полициймейстери адресаткъа, яни Гаспринскийнинъ къолуна, 685 ве 686 номералы газета чыкъармакъ рухсет шахадетнамелерини ве нешир этиледжек газетанынъ программасынынъ копиясыны теслим эткени, ве нешир хакъкъыны дигерине бермеджегини илян эткени, ве къошма варакъада 60 капик къыйметинде учь дамгъалы марканы къошкъаны акъкъында хабер бермекте. Бу хабер 1883 сенеси март 5-те берильгенине коре, иште, газета чыкъармакъ рухсетнамеси Гаспринскийге шу араларда къолуна берильгени белли олмакъта... [2, л. 26].

Нетиджелеме. Эбет, Акъмесджит девлет архивинде сакълангъан ишбу весикъалар айсберг буз къаясынынъ океануснынъ усьтюнден тюртип чыкъкъан ве корюнген тек цивиль бир уджудыр. Акъикъатта исе, о заманда къырымтатарджа шахсий типография ачмакъ меселеси пек де пытракълы олдугъындан, ич де ачыламаз эди.

Гаспринскийнинъ биринджи рефикъасы Самур ханым ве къызы Хатидже Дерекойде яшадыкъларындан, 1904 сенеси догъумлы Дерекойлю оджамыз доцент Мемет оджа Умеров 1970-лерде Ташкенттеки Низами адына пединститутнынъ къырымтатар филологиясы болюгинде кечирген лекцияларында Самур ханымнынъ айткъанларына базанаракъ, бу меселенинъ къаранлыкъта къалгъан базы инджеликлерини ачыкълар эди ки, шулардан - Гаспринский 1870-лерде С.-Петербурггъа къатнадыгъы заман, чар мемурларынынъ «гонълюни алмакъ ичюн» сепет-сепет, торба-торба чешит бахшишлер алып кеткени акъкъындаки эпизод да, занымызджа, чокъ эмиетлидир.

Эр алда, 1883 сенесининъ февралинде алынгъан рухсетнамеден бир ай кечер-кечмез 1883 сенеси апрельнинъ 10-да «Терджиман»нынъ 1-нджи номерини чыкъарып ве бундан сонъки чалышмалары нетиджесинде, Гаспринский къыскъа бир девир ичинде ялынъыз Къырым дегиль, бутюн тюрк ве мусульман дюньясынынъ «уянмасыны» ве цивилизация ёлунда янъы ве гъает сыфытлы бир адым атмасыны дестеклеген эди.

\section{КЪУ ЯДАНЫЯГЬАН ЭДЕБИЯТ}

1. Зайцев И. Письма Исмаил-бея Гаспринского А. С. Суворину и П. П. Вяземскому // Крымское историческое обозрение. 2019. № 1. С. 175-179. 
2. ГАРК (Государственный архив Республики Крым). Ф. 26, оп. 2, д. 1595 , лл. $1,2$.

3. Гаспринский И. Тонъгъуч. (Макъалелер джыйыны). Меджмуа. Эсер-ихаме-и-Исмаил Гаспринский. Таврический Губерниясындан Багъчасарайда къалеме алынмыштыр. Тифлис: «Зия-и-Кавказия» (Унси-заде) матбаасында таб олунмыштыр. 1881.

4. Гаспринский И. Шафакъ. (Макъалелер джыйыны). Меджмуа, № 2. Эсери-хаме-и-Исмаил Гаспринский. Таврический Губерниясындан Багъчасарайда къалеме алынмыштыр. Джюз-у-номерасы 2. Тифлис: «Зия-и-Кавказия» (Унсизаде) матбаасында таб олунмыштыр. 1881.

5. Гаспринский И. Терджиман. Макъалелер. Багъчасарай: Нешрият-иИсмаилие. 1882.

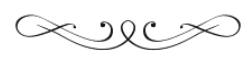

\section{Дипломатическая борьба Исмаила Гаспринского за разрешение на издание газеты «Переводчик-Терджиман»}

\section{Исмаил Керимов}

(Институт истории им. Ш. Марджани АН РТ;

ГБОУВО РК «Крьимкий инженерно-педагогический

университет им. Ф. Якубова»)

Аннотация. В статье на основе архивных материалов рассматриваются попытки И. Гаспринского в 1881-1882 годах, направленные на получение разрешения С.-Петербургского цензурного комитета, открыть в своем доме в Бахчисарае частную типографию. Кратко излагаются материалы, связанные с изданием отдельных листков «Тонгуч» («Первенец», 1881), «Шафак» («Заря», 1881) и «Терджиман» («Переводчик», 1882).

Ключевые слова: Первые издания И. Гаспринского, частная типография в Бахчисарае в 1880-е годы, газетное дело в Крыму в конце XIX века, мусульманская печать в России.

Для цитирования: Керимов И. А. Гаспринскийнинъ газета чыкъармасына рухсетнаме ичюн дипломатик куреши // Крымское историческое обозрение. 2020. № 2. C. 8-18. DOI: $10.22378 /$ kio.2020.2.8-18 
Сведения об авторе: Керимов Исмаил Асанович - доктор филологических наук, профессор, директор Научно-исследовательского института крымскотатарской филологии, истории и культуры этносов Крыма, Крымский инженерно-педагогический университет; ведущий научный сотрудник Крымского научного центра Института истории им. Ш. Марджани АН РТ (420111, ул. Батурина, 7А, Казань, Российская Федерация); alimes@mail.ru

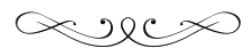

\section{Gasprinsky`s diplomatic struggle for permission to publish a newspaper}

\section{Ismail Kerimov}

(Sh. Marjani Institute of History of Tatarstan Academy of Sciences; SBEEHE RC «F. Yakubov Crimean Engineering and Pedagogical University»)

Abstract: The given article, on the basis of archive documents, reveals the information concerning the attempts of I. Gasprinsky in (1881-1882) to obtain permission from S. Petrsbourg Censorship Committee to open a private printing house in his own home, in Bakhchisaray. The informationl, about publication of separate pages of "Tonguch"/"First-born," (1881), "Shafak"/ "Dawn" and "Tercuman"/ "Translator" (1882) are given in precise form.

Keywords: first editions of I. Gasprinski, private printing house in Bakhchisaray in 1880s, newspaper business in the Crimea at the end of XIX century, Muslim press in Russia

For citation: Kerimov I. A. I. Gasprinsky`s diplomatic struggle for permission to publish a newspaper. Krymskoe istoricheskoe obozrenie $=$ Crimean Historical Review. 2020, no. 2, pp. 8-18. DOI: 10.22378/kio.2020.2.8-18

\section{REFERENCES}

1. Zaycev I. Pis'ma Ismail-beya Gasprinskogo A. S. Suvorinu i P. P. Vyazemskomu [Letters of Ismail Bey Gasprinsky to A. S. Suvorin and P. P. Vyazemsky] Krymskoe istoricheskoe obozrenie [Crimean historical review]. 2019. No 1. Pp. 175-179.

2. State archive of the Republic of the Crimea. Fund 26, in. 2, file 1595, pp. 1, 2. 
3. Gasprinskij I. Ton"'g"uch [First-born]. Collected papers. Tiflis: printing house "Zia-I-Kavkaziya" (Unsi-zade). 1881.

4. Gasprinskij I. Shafak [Dawn]. Collected papers. Tiflis: printing house "Zia-IKavkaziya” (Unsi-zade). 1881.

5. Gasprinskij I. Translator. Articles. Bakhchysaray: publishing house of the "Neshriyat-i-Ismailie". 1882.

About the author: Kerimov Ismail Asanovich - Dr. Sci. (Philology), Professor, Director of the Scientific Research Institute of the Crimean philology, history and culture of the Crimean ethnos, SBEEHE RC "F. Yakubov Crimean Engineering and Pedagogical University"; Leading Researcher of the Crimean Scientific Center of Sh. Marjani Institute of History of Tatarstan Academy of Sciences (420111, Kazan, Baturin Str., 7A, Russian Federation); alimes@mail.ru

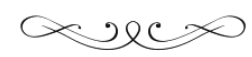

